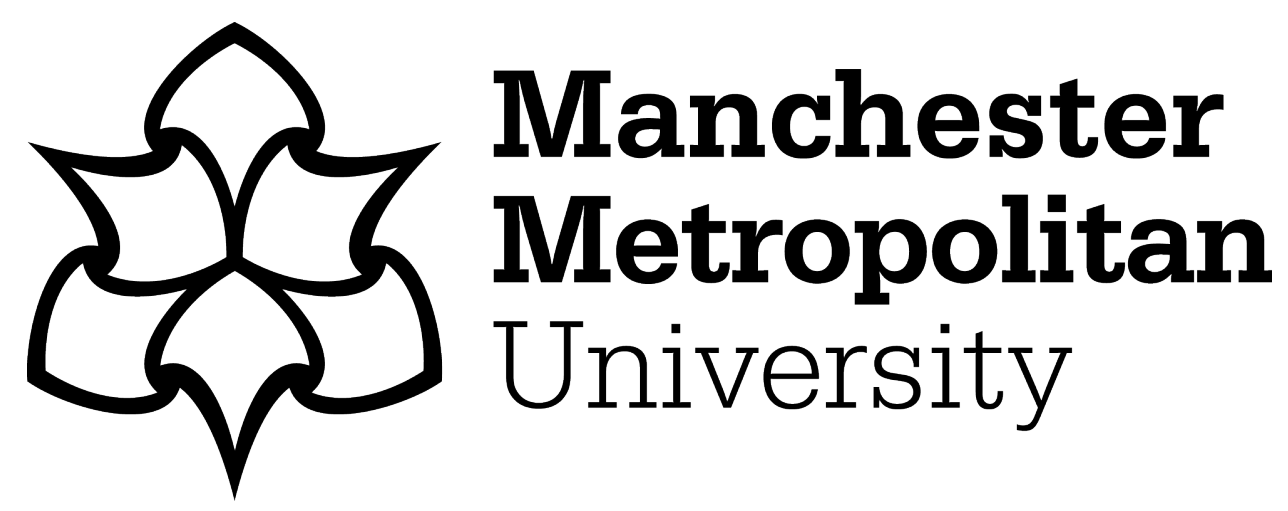

Rampasso, IS, Anholon, R, Silva, D, Cooper Ordoñez, RE, Santa-Eulalia, LA, Quelhas, OLG, Leal Filho, W and Granada Aguirre, LF (2019) Analysis of the perception of engineering students regarding sustainability. Journal of Cleaner Production, 233. pp. 461-467. ISSN 0959-6526

Downloaded from: https://e-space.mmu.ac.uk/623691/

Version: Accepted Version

Publisher: Elsevier

DOI: https://doi.org/10.1016/j.jclepro.2019.06.105

Usage rights: Creative Commons: Attribution-Noncommercial-No Derivative Works 4.0

Please cite the published version 


\title{
Analysis of the perception of engineering students regarding sustainability
}

\author{
Rampasso IS, Anholon R, Silva D, Cooper Ordoñez RE, Santa-Eulalia LA, Quelhas \\ OLG, Leal Filho W, Granada Aguirre LF \\ Journal of Cleaner Production 233:461-467 01 Oct 2019, \\ https://www.sciencedirect.com/science/article/pii/S0959652619320633?via\%3Dihub
}

\begin{abstract}
The objective of this research is to evaluate the engineering students' perception regarding sustainability. For this, a survey was developed based on sustainability parameters from a detailed analysis of the Global Reporting Initiative (GRI) and the Brazilian Institute of Corporate Governance (IBGC). The parameters were initially divided into seven groups: Financial and Productivity Aspects (FPA); Concern with employees (CWE); Support for Local Communities (SLC); Ethical and corporate governance issues (ECI); Environmental aspects (ENA); Sustainable aspects in the operations network (SON); Customers, development of new products and services (CPS). The survey was conducted with engineering undergraduate students from two Brazilian universities. The data were analyzed through structural equation modeling technique, more precisely by means of the PLS-SEM algorithm. We obtained 162 answers, which enabled the validation of the model tested, and showed that the students, in general, do not consider support for local communities and concern with employees when they are analyzing sustainability. Additionally, the most important construct for them is the customers, development of new products and services. This is an exploratory study and we believe that these findings may contribute to expand the debate about the sustainability insertion in engineering courses, helping educators in their didactic activities. As future research, it is suggested the replication of this study in other higher education institutions.
\end{abstract}




\section{Introduction}

Social and environmental degradation has been a matter of increasing concern to many stakeholders. This problem is even more difficult to handle when it is considered the necessity of economic growth to meet society demands (Fiorini and Hoekman, 2018; Marques et al., 2018; Opoku, 2019; Saunila et al., 2018). In this sense, the 17 Sustainable Development Goals (SDGs), from United Nations (UN) perform an important role to establish guidelines that companies, government and societies should seek in order to do not prejudice the future generations (Brundtland, 1987; Sales Moreira, 2018; Srivastava, 2018; UN, 2017). The Global Reporting Initiative (GRI) is aligned with these guidelines and is an important guide for companies to understand what are the items that should be reported regarding sustainability dimensions (GRI, 2018; Rosati and Diniz Faria, 2018). Additionally, ethical issues are also associated with sustainability and, in this context, guides such as those disseminated by Brazilian Institute of Corporate Governance (IBGC) play an important role in the quest for sustainable development (IBGC, 2007). However, for organizations to insert sustainable practices into their routines, professionals must be prepared.

In this sense, there is a growing need for universities to prepare their undergraduate students to work towards sustainable development (Balsiger, 2015; Hollos et al., 2012; Iyer-Raniga and Andamon, 2016; Sharma et al., 2017). Nonetheless, there are many factors that hamper the satisfactorily implementation of an Education for Sustainable Development (ESD). Among them, it may be highlighted the transdisciplinary character of sustainability and the excessive focus on environmental issues to the detriment of economic and social issues. Thus, it is evident in the literature that there are many challenges to be overcome by higher education institutions to achieve an ESD (Balsiger, 2015; Guerra, 2017; Hanning et al., 2012; Rampasso et al., 2018a). In addition to the challenges intrinsic to this insertion, the problems arising from the absence or even poor implementation an ESD must also be considered.

An important consequence of this difficulty is the negative impact that the lack of an ESD can generate in the undergraduate students when considering the importance of the academic formation in the students world view (Dagiliūte et al., 2018). There are studies arguing that undergraduate students tend to give greater importance to the parameters related to environmental sustainability (Dagiliūtè et al., 2018; Yuan and Zuo, 
2013), which is related to the difficulty of higher education institutions in providing a broader vision of sustainability (Guerra, 2017; Tejedor et al., 2018).

In engineering education this reality is no different and, given the importance that future engineers have for sustainable development, this theme has been receiving prominence in the literature over the years (Ashford, 2004; Hanning et al., 2012; Holgaard et al., 2016; McCormick et al., 2015; Segalàs et al., 2012; Sharma et al., 2017). Given this context, the present research aims to evaluate the students' perception of engineering in relation to sustainability.

For this, the following section will introduce the theoretical background regarding sustainability insertion into engineering education. Section 3 will present the methodological procedures that were used for data analysis, which is presented in section 4. The discussion and conclusion are in section 5, followed by bibliographical references.

\section{Theoretical Background}

\section{Sustainability insertion into engineering education}

Due to the importance that engineering has for society in all its aspects (ref), the teaching of this career has been gaining prominence in academic research and discussion forums for educators. Many aspects are discussed, highlighting the sustainability which can greatly contribute to the training of better prepared professionals (Rampasso et al., $2018 b$ ). In this context, the present literature review seeks to present the results of some researches that contributes to the debate on the subject.

Tejedor et al. (2018) stresses that in order to be effective, the insertion of sustainability in engineering education must be linked to the development of systemic thinking and transdisciplinarity. This perspective is corroborated by Guerra (2017), in which it is emphasized the important role played by PBL (Problem-Based Learning) to enable the teaching of transdisciplinarity concepts for engineering students. Additionally, the author explain the importance of teaching undergraduate students in order to insert the concerns related to sustainability issues into their professional identities.

Due to the important role played by engineers in societies to enable the sustainable

development, there are many examples of cases reporting experiences of sustainability insertion into engineering courses (Thürer et al., 2018). Focusing on environmental 
sustainability, Ramanujan et al. (2019) presented an approach to insert this dimension of sustainability into mechanical engineering undergraduate courses. The teaching approach used is the classified as a guided discovery instruction. In this kind of teaching method, students need to participate more than in traditional teaching methods. They must seek to solve questions and understand the meaning of their findings. Everything guided by a professor. In their research, Ramanujan et al. (2019) used this approach to teach mechanical engineering students to consider environmental sustainability when performing a shape synthesis design task. The authors found out that guided discovery instruction was effective in enabling students to understand complex issues, such as the difficulties to consider the environmental negative impacts of designs, as well as the importance to take it into account in their decisions.

Although much more discussed nowadays, the analysis of sustainability insertion into engineering undergraduate courses are not new. In 2005, Kumar et al. (2005) evaluated how this issue was being considered at Michigan Technological University, in the course of mechanical engineering. Based on experiences from this university, the authors highlight the need for mechanical engineers to consider the consequences of their decisions not only in the technical perspective but also the impacts for society, environment and economy. Using the concept of interdisciplinary, the authors point out the necessity to relate topics from engineering courses with subjects from humanities and social sciences in order to properly insert sustainability into undergraduate courses. Regarding the approach, they highlight the usefulness of experiences of teaching in which students needs to be more active than they are in traditional teaching methods.

Holgaard et al. (2016) compare two experiences of sustainability insertion into engineering curricula, one in Denmark and the other in Australia. The authors also provide a conceptual framework to explain the sustainability insertion mechanism evaluated. In their framework, actors, resources and activities are considered for both internal and external environment. This framework provides the possibility to analyze how the mentioned insertion should be done or is being done. Both cases studied were analyzed through this framework. In Denmark, authors verified that researches on this theme were growing and partnerships with United Nations Organization for Education, Science and Culture (UNESCO) were enabling initiatives regarding problem-based and project-based learning (PBL). In Australia, the scenario was different, there, the starting point is based in practical experiences. Based on the analysis of these cases, the authors 
developed a five-steps model to guide this insertion into engineering curricula. The first step is to identify the activities, actors and resources that the higher educational institution has to promote (or that is promoting) an ESD. The second step is the identification of enablers inside the institutions. The third step is the analysis of the country context and evaluation of former experiences. The forth step is the development of a path to be followed to materialize the insertion. The last step is the establishment of strategic partnerships to enable a long term ESD implementation.

Analyzing the curricular restructuring of a Chemical Engineering course in South Africa, von Blottnitz et al. (2015) focused on the introduction of sustainability concepts in the course. The authors verified that complex issues can be taught in the beginning of undergraduate courses since it be properly done. An important tool used to enable it was a project work, which was used for students to apply the theory and to develop abilities. The development of the capacity for critical analysis in the students was considered well succeed.

Leal Filho et al. (2018) performed case studies in seven countries to analyze the education for sustainability in higher educational institutions of these countries. Two of these studies involved engineering undergraduate courses: Manchester Metropolitan University, UK; and Polytechnic University of Catalonia, Spain. In Manchester Metropolitan University, engineering undergraduate students were involved in PBL interdisciplinary projects related to local community. A group of these students earned the Global Dimension in Engineering Education European award, an award to initiatives for sustainable development in engineering. In Polytechnic University of Catalonia, initiatives to promote training focused on sustainable development into engineering courses have been taken for years, in order to develop critical thinking in students. Participation in Non-Governmental Organisations (NGOs) are used to enable academic activities in this sense.

Rampasso et al. (2018b), through action research, analyzed the development of critical thinking regarding sustainability in students of mechanical engineering at University of Campinas. The research was conducted in a discipline called "Productive Systems" and focused on the economic, environmental and social aspects of sustainability. The main difference of the approach used in the analyzed discipline was the focus on social and environmental aspects of sustainability, since the economic dimension is traditionally addressed in this kind of course. During the explanatory classes, 
different points of views are presented to the students regarding organization of work, that is, besides the traditional perspective of it, the critics made for this organization of work are also presented. Positive and negative impacts for local communities and for the environment are discussed too. A final project of the discipline demands that students consider all these perspectives to present a reasonable productive system. The authors highlight the importance of using innovative ways of teaching to properly insert sustainability into engineering education.

From the information presented, it can be seen that the debate about the insertion of sustainability in engineering courses can still be expanded. And, understanding how students think about sustainability can contribute to improving the training of engineers. Thus, the importance of the present study.

\section{Methodological Procedures}

This section is dedicated to the presentation of the methodological procedures used to conduct this research. We believe they can be very useful to other researchers who want to understand how engineering students think in terms of sustainability. The reliability of this research is thus sought.

\subsection{Research classification}

This research was based in three research strategies: literature review, to base the research's importance and to collect data to develop the questionnaire; a panel of experts, to organize the constructs of the model to be tested; and a survey with undergraduate students, in order to understand how they think about sustainability, that is, what are the parameters that really matters when sustainability is considered. The simultaneous use of qualitative and quantitative approaches used characterized a mixed approach (Gray, 2017). The statistical treatment of the data is quantitative, while the analysis of the parameters and the panel of experts are characterized as qualitative. Additionally, this research presents an applied nature and exploratory objectives. The data was collected through a questionnaire and analysed via Partial Least Squares - Structural Equation Modeling (PLS-SEM). The next subsections detail better the steps taken. 


\subsection{Compilation of parameters and panel of experts}

The compilation of the parameters used were conducted through an analysis of the Global Report Initiative (GRI) and the Sustainability Guide for Companies of the Brazilian Institute of Corporate Governance (IBGC). The parameters were divided according to the panel of experts, which was composed by 8 members. They all have experience in sustainability issues. The members selected have more than ten years of experience. The panel of experts is a qualitative technique that may be used in a preliminary phase of the research (Campos et al., 2010; Pinheiro et al., 2013). In this research, one meeting was conducted and the consensus regarding the constructs was achieved in the fourth round. The result of the panel was the first model to be tested through PLS-SEM. The Table 1 was structured with the parameters used in this research.

Table 1. Sustainability parameters. Source: Adapted from (GRI, 2018; IBGC, 2007)

\begin{tabular}{|c|c|c|}
\hline Constructs & Code & \multirow{5}{*}{$\begin{array}{l}\text { Parameters } \\
\text { Generation and distribution of revenues for investors. } \\
\text { Concern about investing in projects that guarantee the } \\
\text { continuity of the company in the long term. } \\
\text { Analysis of risks and opportunities made on an ongoing basis. } \\
\text { Constant concern about increased productivity and efficiency. }\end{array}$} \\
\hline \multirow{4}{*}{$\begin{array}{l}\text { Financial } \\
\text { and } \\
\text { Productivity } \\
\text { Aspects } \\
\text { (FPA) }\end{array}$} & FPA_1 & \\
\hline & FPA_2 & \\
\hline & FPA_3 & \\
\hline & FPA_4 & \\
\hline \multirow{5}{*}{$\begin{array}{l}\text { Concern with } \\
\text { employees } \\
\text { (CWE) }\end{array}$} & CWE_1 & \multirow{5}{*}{$\begin{array}{c}\text { Combat any kind of discrimination of gender, age, salary } \\
\text { aspects, etc. } \\
\text { Granting benefits to employees (examples: health plan, } \\
\text { retirement plan, etc.) } \\
\text { Providing training and refresher courses / training to employees } \\
\text { Maintaining constant discussions and discussions with unions in } \\
\text { the categories. } \\
\text { Concern about minimizing (or eliminating) risks of } \\
\text { occupational accidents and diseases. }\end{array}$} \\
\hline & CWE_2 & \\
\hline & CWE_3 & \\
\hline & CWE_4 & \\
\hline & CWE_5 & \\
\hline \multirow{4}{*}{$\begin{array}{l}\text { Support for } \\
\text { Local } \\
\text { Communities } \\
\quad \text { (SLC) }\end{array}$} & SLC_1 & \multirow{4}{*}{$\begin{array}{l}\text { Investments in projects that favor local communities (e.g. health } \\
\text { centers, schools, etc.). } \\
\text { Hiring employees living in local communities, including } \\
\text { employees for management positions. } \\
\text { Constant monitoring of needs presented by local communities. } \\
\text { Establishment of goals and performance indicators to follow the } \\
\text { evolution of social projects. }\end{array}$} \\
\hline & SLC_2 & \\
\hline & SLC_3 & \\
\hline & SLC_4 & \\
\hline \multirow{2}{*}{$\begin{array}{l}\text { Ethical and } \\
\text { corporate } \\
\text { governance } \\
\text { issues (ECI) }\end{array}$} & ECI_1 & \multirow{2}{*}{$\begin{array}{l}\text { Establish guidelines and mechanisms to combat internal } \\
\text { corruption. } \\
\text { Compliance with laws and transparency in disclosure of } \\
\text { information. }\end{array}$} \\
\hline & ECI_2 & \\
\hline
\end{tabular}




\begin{tabular}{|c|c|c|}
\hline & ECI_3 & $\begin{array}{c}\begin{array}{c}\text { Absence of anti-competitive behavior (e.g. antitrust and } \\
\text { monopoly practices) }\end{array} \\
\text {. }\end{array}$ \\
\hline & ECI_4 & $\begin{array}{c}\text { Excellence in the management of tax benefits obtained from the } \\
\text { government. }\end{array}$ \\
\hline & ECI_5 & Equal treatment of all stakeholders \\
\hline \multirow{4}{*}{$\begin{array}{l}\text { Environment } \\
\text { al aspects } \\
\text { (ENA) }\end{array}$} & ENA_1 & Adequate use of energy resources and water resources. \\
\hline & ENA_2 & $\begin{array}{c}\text { Minimizing emission of polluting gases (e.g. CO2, CH4, N2O, } \\
\text { HFCs, PFCs, SF6, NF3, etc.) }\end{array}$ \\
\hline & ENA_3 & Compliance with environmental laws and regulations. \\
\hline & ENA_4 & Concern about reverse logistics. \\
\hline \multirow{3}{*}{$\begin{array}{l}\text { Sustainable } \\
\text { aspects in the } \\
\text { operations } \\
\text { network } \\
\text { (SON) }\end{array}$} & SON_1 & $\begin{array}{c}\text { Application of criteria that contemplate all aspects of } \\
\text { sustainability in the selection of suppliers. }\end{array}$ \\
\hline & SON_2 & $\begin{array}{l}\text { Insertion of the sustainable aspects in the projects developed } \\
\text { with the other partners of the operations network. }\end{array}$ \\
\hline & SON_3 & $\begin{array}{l}\text { Concern about the sustainable performance of the whole } \\
\text { productive network and not only the company. }\end{array}$ \\
\hline \multirow{4}{*}{$\begin{array}{l}\text { Customers, } \\
\text { development } \\
\text { of new } \\
\text { products and } \\
\text { services } \\
\text { (CPS) }\end{array}$} & CPS_1 & $\begin{array}{l}\text { Understanding customer needs in relation to new products, } \\
\text { services and sustainable trends. }\end{array}$ \\
\hline & CPS_2 & $\begin{array}{l}\text { Insertion of sustainability in the development of new products } \\
\text { or services. }\end{array}$ \\
\hline & CPS_3 & $\begin{array}{l}\text { Analysis of the perception of the client regarding the use of a } \\
\text { product or service that contemplates the sustainable aspect. }\end{array}$ \\
\hline & CPS_4 & $\begin{array}{l}\text { Concern to spread concepts of sustainability for all clients and } \\
\text { society in general. }\end{array}$ \\
\hline $\begin{array}{l}\text { General note } \\
\text { for } \\
\text { sustainability } \\
\text { (GNS) }\end{array}$ & GNS & General note for sustainability (GNS) \\
\hline
\end{tabular}

\subsection{Survey}

From the parameters collected in GRI and IBGC a questionnaire was developed and applied in undergraduate students from University of Campinas (Unicamp) and Federal Fluminense University (UFF - campus Niterói). The students of UFF were from Mechanical Engineering. The students of Unicamp were from Mechanical Engineering and Control Automation Engineering. Both courses of Unicamp were used due to the similar structure of them.

The questionnaire had 38 questions ( 8 related to respondents' information and 30 regarding the model to be validated). For each of the aforementioned parameters, the respondents should point to a scale from 0 to 10 as they observed it in companies in Brazil. At the extremes, note 0 indicates the non-observation of the parameter and note 10 
indicates intense observation of said parameter. The questionnaire was approved by the ethics committee in research, as required for research in Brazil.

A total of 1,552 questionnaires were sent, for 1,151 students of Unicamp and 401 students of UFF. After two months, 162 questionnaires were received, characterizing a response rate of $10.43 \%$. The sample was characterized by $79 \%$ of students from Unicamp and $21 \%$ from UFF; $83 \%$ of mechanical Engineering students and $17 \%$ of Control Automation Engineering. Regarding the percentage of the course already completed, $18.5 \%$ completed until $25 \% ; 21.6 \%$ completed between $25 \%$ and $50 \% ; 24.1 \%$ completed between $50 \%$ and $75 \% ; 35.8 \%$ completed between $75 \%$ and $100 \%$. All the respondents were over 18 years old.

\subsection{Data analysis}

The Structural Equation Modeling (SEM) "is a powerful statistical approach for the testing of hypotheses about networks of direct and indirect theoretical causal relationships in complex data sets with intercorrelated dependent and independent variables" (Lamb et al., 2014, p. 2434). Linear relationships between latent and observed variables can be tested from hypothesized models (Harring et al., 2015). There are two techniques in SEM, the first is the Partial Least Squares (PLS) method and the second is the covariance based (CB) method (Hair et al., 2014). PLS is a more appropriate approach for research with causal-predictive analysis, allowing exploratory research to be carried out. While CB is best suited to test more established theories (Nejati et al., 2017). This study uses the first technique, since it presents an exploratory character.

PLS-SEM has been used in the academic world as a tool for data analysis (Chekima et al., 2017; Diaz-Ruiz et al., 2018; Rehman et al., 2016). Its popularity is partly due to the fact that it is a tool that does not require large samples to analyze data (Kuei et al., 2015; Laguir et al., 2015). In addition, because it is a technique called soft modeling, PLS has greater flexibility in handling data than other techniques. However, it is important to note that only distribution assumptions are characterized by being "soft", the model estimates provided by this technique are very robust. The term "soft" is more related to the idea of "plasticity" or "flexibility" of the technique (Hair et al., 2014). The path coefficient presented by PLS-SEM represents the strength of association between the analyzed constructs (Hwang et al., 2016). The PLS-SEM aims to maximize the 
explained variance of dependent latent constructs (Gallardo-Vázquez and SanchezHernandez, 2014). This approach is divided into nine steps, described below. These steps are based on Ringle et al. (2014).

The first step is to define a structural model to be statistically tested. This model should take into account the initial hypotheses of research. After the model is structured, the minimum sample size should be calculated. For this, the $G *$ Power software may be used (second step), with test power of $80 \%$ and median effect size of $15 \%$, according to the recommendations of Hair et al. (2014).

The third step consists in the validation of the structural model using the least squares (PLS) method. For this, the collected data must be saved in .cvs format and must be loaded in the SmartPLS software. When running the PLS algorithm, the following parameters should be used: Path Weighting Scheme, zero mean and variance of 1 , the maximum number of interactions to converge the model was 300; and the criterion of stopping the calculations was 0.00001 . A series of information is then provided by the software and the criteria for analyzing this information are detailed in the next steps (Ringle et al., 2014).

In step 4, the convergent validity is measured through the analysis of the Average Variance Extracted (AVE). For results to be considered satisfactory, all values for AVEs must be greater than 0.50 . Step 5 consists of checking the internal consistency, through Cronbach's Alpha and Composite Reliability. To be satisfactory, the values should be greater than 0.60 and 0.70 for Cronbach's Alpha and Composite Reliability, respectively. According to Ringle et al. (2014), the Composite Reliability is more appropriate for the Modeling of Structural Equations.

The discriminant validity is evaluated in step 6. This is the verification of the correct allocation of the parameters in their respective constructs and the certification that the constructs are independent. For this, Ringle et al. (2014) recommend cross-load analysis. Through it, one must verify if the factorial load of each parameter is greater in its own construct than in other constructs. In step 7, the Pearson's coefficients $\left(\mathrm{R}^{2}\right)$ are analyzed. $\mathrm{R}^{2}$ values of $2 \%, 13 \%$ and $26 \%$ are considered low, medium and great effect for administrative sciences (Cohen, 1988).

Step 8 is characterized by the evaluation of linear correlations and regressions. When running Bootstrapping in SmartPLS software, the values obtained must all be 
greater than 1.96 (which shows p-values $\leq 0.05$ ). This indicates that the correlations and regressions are valid for at least $95 \%$ of the cases. It is important to note that Bootstrapping presents different results (although very close) every time it is run, since it uses random sub-samples.

Finally, step 9 is composed by the analysis of the Relevance or Predictive Validity $\left(\mathrm{Q}^{2}\right)$ and Cohen Indicator or Communality $\left(\mathrm{f}^{2}\right)$ parameters. To obtain them, it is necessary to run Blindfolding. Values above zero for Predictive Validity and above 0.15 for Communality are considered satisfactory (Ringle et al., 2014). Through these nine steps, it is possible to statistically validate a model via PLS-SEM. These steps were performed in this research.

\section{Results}

Panel of experts

After collecting several parameters from GRI and IBGC, the panel of experts was performed. As a result of the panel of experts, the first theoretical model to be tested was obtained. The division of the parameters into more than three constructs is due to the fact that there are parameters that would fit into more than one construct, for example, the parameter "Establish guidelines and mechanisms to combat internal corruption" could be allocated either into social or economic dimension of sustainability. As well as "Compliance with laws and transparency in disclosure of information" could fit into social, economic or even environmental dimensions. This discussion was performed during the panel of experts and resulted in the division of the parameters into seven constructs are presented in Figure 1. 


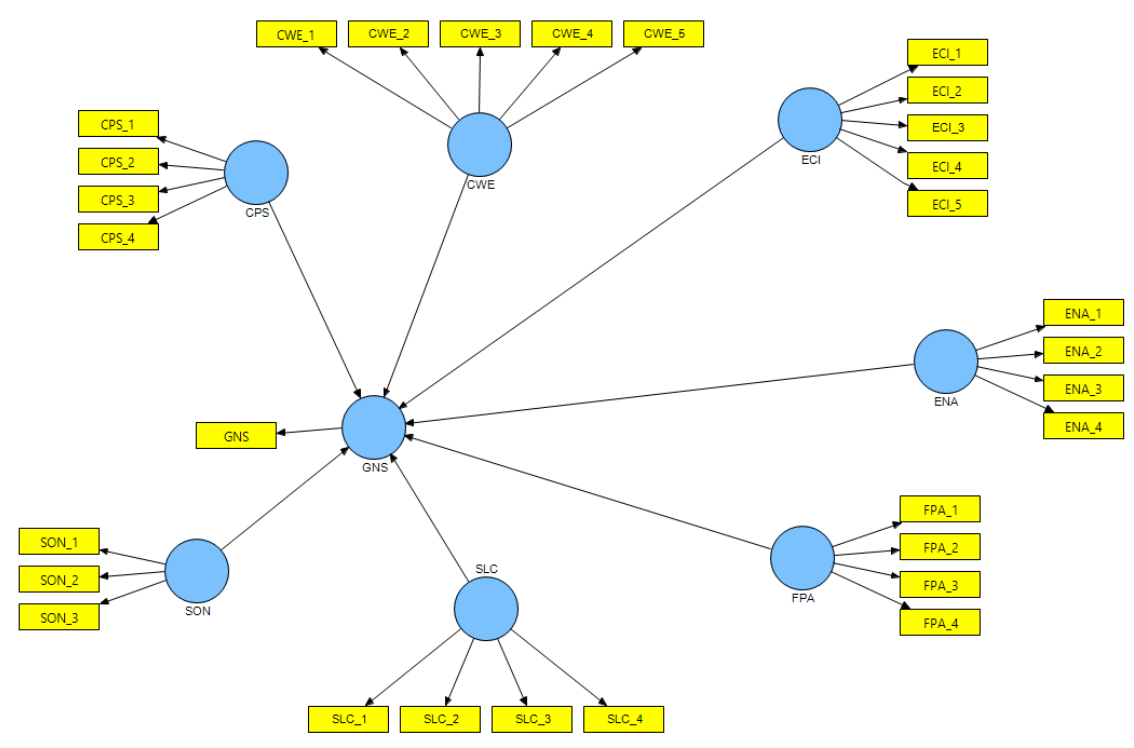

Figure 1. First Theoretical Model. Source: Authors

\section{Problems faced during the validation through PLS-SEM}

The validation through PLS-SEM aims to obtain the best fit of the model. Therefore, when results are not in accordance to the literature, researchers should perform changes in order to define this adjustment. In this study, the first attempt to validate the model presented a problem in calculating the AVE for the ECI construct. The AVE was less than 0.5. To solve this, the parameter with the lowest factorial load (ECI_3 - Absence of anticompetitive behavior (e.g. antitrust and monopoly practices)) was removed from the construct. This change increased the AVE of the construct ECI, showing that the other parameters were sufficient to explain the construct.

The second problem faced in the model was when the Bootstrapping was run. After removing the two with the lowest values (SLC and CWE), the model was validated, with all values above 1.96. The next subsection presents the validation of the final model, obtained after these adjustments. The final model design is presented in Figure 2. 


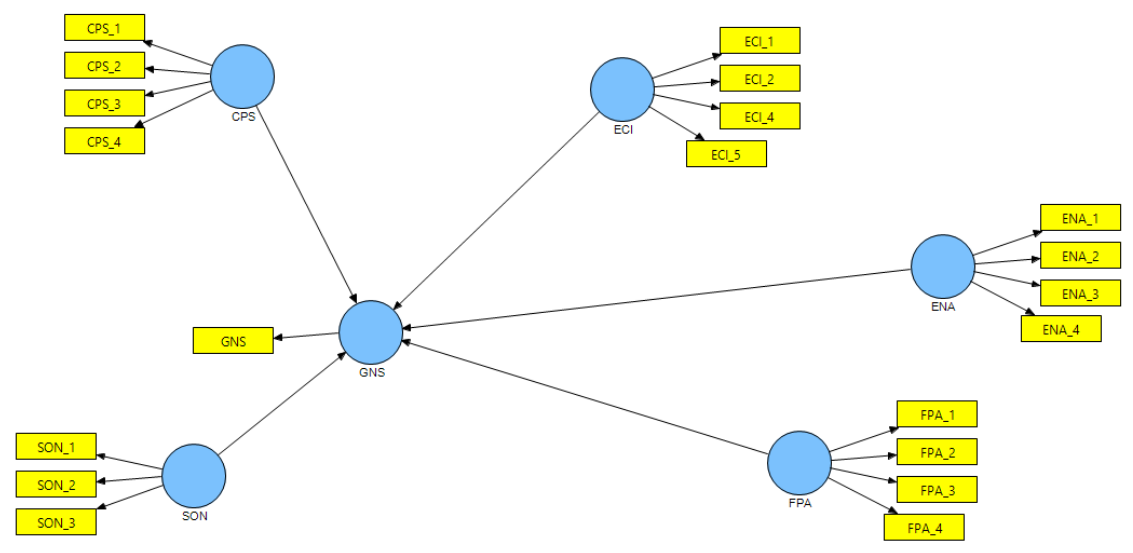

Figure 2. Final Model. Source: Authors

\section{Validation through PLS-SEM}

With the theoretical model (step 1), the second step to take was the sample calculation. The software G*Power presented the need to obtain 103 respondents to have a test power of $80 \%$. Once we had 162 respondents, the test power is $96,24 \%$. After this, the PLS Algorithm was run (step 3) and presented the following Figure 3. 


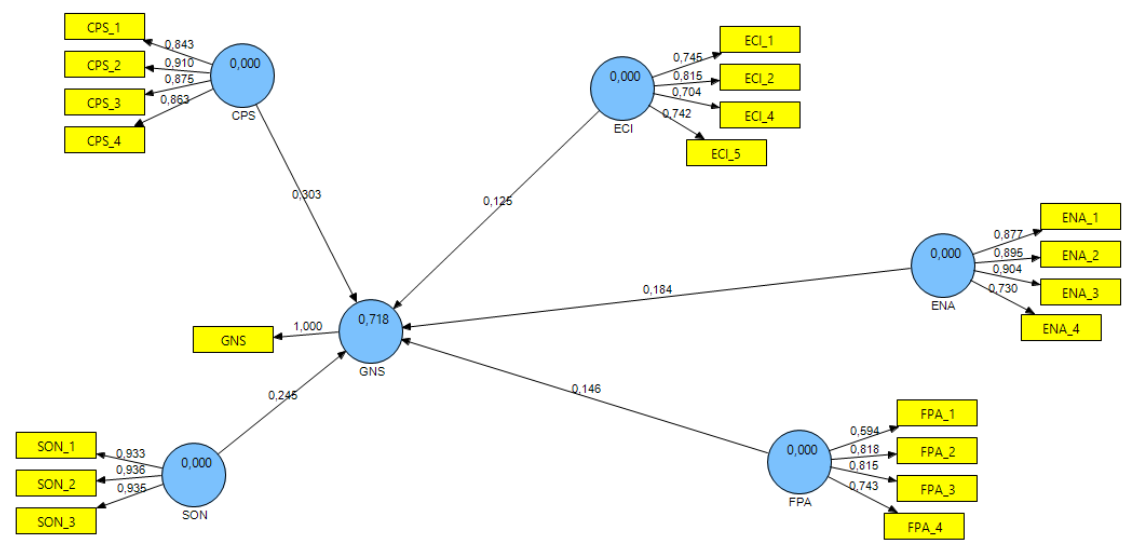

Figure 3. Values obtained by with the PLS-SEM Method. Source: Authors

The Table 2 shows the results presented in the report of PLS Algorithm. They are used to validate the next steps.

Table 2. Quality Criteria results. Source: Authors

\begin{tabular}{cccc}
\hline Constructs & AVE & $\begin{array}{c}\text { Composite } \\
\text { Reliability }\end{array}$ & $\begin{array}{c}\text { Cronbachs } \\
\text { Alpha }\end{array}$ \\
\hline CPS & 0.763 & 0.928 & 0.896 \\
ECI & 0.567 & 0.839 & 0.744 \\
ENA & 0.730 & 0.915 & 0.875 \\
FPA & 0.559 & 0.833 & 0.731 \\
GNS & 1.000 & 1.000 & 1.000 \\
SON & 0.873 & 0.954 & 0.927 \\
\hline
\end{tabular}

As it can be verified in Table 2, all the values from AVE were higher than 0.50 (step 4). Values of Cronbach's Alpha and Composite Reliability were also validated (step 5). These steps checked the convergent validity and the internal consistence of the model. That is, the step 4 shows that the "the model converges to a satisfactory result" (Ringle et al., 2014, p. 62) and the step 5 proves that no bias was detected in the sample data (Ringle et al., 2014). 
In step 6, it was verified whether the parameters were correctly allocated in their constructs. The results showed that all the parameters presented their factorial loads higher in their own constructs than in the others, showing that they were correctly placed. In the step 7, the Pearson's coefficient $\left(\mathrm{R}^{2}\right)$ was checked. In this research, there is only one $\mathrm{R}^{2}$ since just one endogenous construct (Ringle et al., 2014). The value of $\mathrm{R}^{2}$ was 0.718 , which means that the model presents a great effect regarding its adjustment quality.

The step 8 was characterized by the linear correlations and regressions analysis. Through Bootstrapping, it was possible to verify that all the correlations and regressions are valid for at least $95 \%$ of the cases, since no values were below 1.96 , as it is showed in Figure 4.

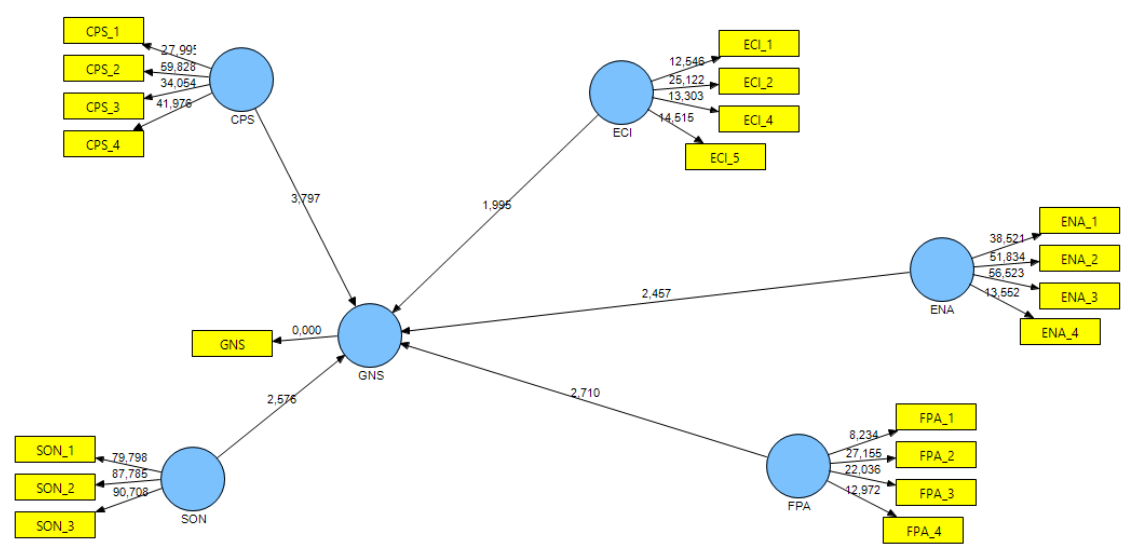

Figure 4. Values from Bootstrapping Algorithm. Source: Authors

In the last step, Predictive Validity $\left(\mathrm{Q}^{2}\right)$ and Communality $\left(\mathrm{f}^{2}\right)$ parameters were evaluated and presented satisfactorily results, as it is shown in Table 3. In the Predictive Validity, it is possible to evaluate how close the model is from what it was expected and Communality shows the usefulness of the construct for the model. It is important to highlight that the construct GNS does not present a communality value since it is the dependent variable from the model. 
Table 3. Blindfolding results. Source: Authors

\begin{tabular}{ccc}
\hline Constructs & Predictive Validity & Communality \\
\hline CPS & 0.589 & 0.589 \\
ECI & 0.276 & 0.276 \\
ENA & 0.549 & 0.549 \\
FPA & 0.281 & 0.281 \\
GNS & 0.660 & - \\
SON & 0.696 & 0.696 \\
\hline
\end{tabular}

After validating the model, the next section will present the discussions and conclusions regarding these results.

\section{Discussion and Conclusion}

The validation performed here enable the establishment of a series of findings. The first issue to be discussed is the elimination of the parameter "Absence of anti-competitive behavior (e.g. antitrust and monopoly practices)" (ECI_3) and the constructs "Concern with employees" (CWE) and "Support for Local Communities" (SLC). The elimination of ECI_3 was performed through results from AVE. This means that the construct "Ethical and corporate governance issues" (ECI) can be explained only by the other four parameters. That is, according to the students' perception, "Establish guidelines and mechanisms to combat internal corruption"; "Compliance with laws and transparency in disclosure of information"; "Excellence in the management of tax benefits obtained from the government"; and "Equal treatment of all stakeholders" are sufficient to explain "Ethical and corporate governance issues". The reason for the eliminations of CWE and SLC is also related to the students' perceptions. In this case, the students from our sample did not consider these issues when they are analyzing sustainability. That is, for them, the parameters related to employees and local communities are not included in their sustainability analysis. The reason for this is due to the fact that the students have low correlation with the overall sustainability grade, i.e. when students evaluate sustainability, they are not considering those parameters.

Another item important to consider is the path coefficients. The construct with the greatest influence on sustainability value is the "Customers, development of new products and services" (CPS $\rightarrow$ 0.303), followed by "Sustainable aspects in the operations network" (SON $\rightarrow$ 0.245). This result is interesting when confronted with the literature. 
There are many examples of researches that point out the excessive focus on environmental sustainability as a problem in engineering education (Dagiliūtè et al., 2018; Edvardsson Björnberg et al., 2015; Guerra, 2017; Yuan and Zuo, 2013). In this research, the students do not this as a primary issue (its construct - ENA - was the third highest grade). The worst value of path coefficient was presented by ECI. This means that students consider its parameters as the least important from the model.

There are lessons that may be learned from these findings. The first one to be mentioned is that PLS-SEM was confirmed as a useful tool to understand how the students think and, therefore, establish plans to improve what is not satisfactory. As a consequence of it, analyzing the results of this study, it is clear that students from the sample must be better prepared better in relation to social aspects of sustainability, especially the concerns regarding employees and local communities. This is particularly important when it is considered the role of engineers in the development and improvement of production systems (Rampasso et al., 2018b). Another issue relevant to be addressed is the fact that maybe the environmental sustainability has not been emphasized enough in engineering courses. The link between sustainability concerns and the development of new products and services is important but it is not sufficient. Engineers must present reasonable levels of concern regarding environmental issues, such as a proper use of water and energy, emission of polluting gases, legislations, as well as they must be aware that they are responsible for what they produce and that the disposal they products is the responsibility of them and their companies.

Although it is an exploratory research, the findings here can be useful for researchers to use this study as starting point for others studies and for professors and coordinators from higher education institutions that can use these findings to analyze their own engineering courses and evaluate what they need to prioritize in the improvements they perform. As a future research, it is recommended that the replication of this methodological procedure in undergraduate engineering courses from other higher education institutions in order to wide the debate about students' perception regarding sustainability issues.

\section{References}

Ashford, N.A., 2004. Major challenges to engineering education for sustainable 
development. Int. J. Sustain. High. Educ. 5, 239-250. https://doi.org/10.1108/14676370410546394

Balsiger, J., 2015. Transdisciplinarity in the class room? Simulating the co-production of $\begin{array}{llll}\text { sustainability } & \text { knowledge. } & \text { Futures } & 65,\end{array}$ https://doi.org/10.1016/j.futures.2014.08.005

Brundtland, G., 1987. Our common future, World Commission on Environment and Development. Oxford University Press, Oslo.

Campos, R.T.O., Miranda, L., Gama, C.A.P. da, Ferrer, A.L., Diaz, A.R., Gonçalves, L., Trapé, T.L., 2010. Oficinas de construção de indicadores e dispositivos de avaliação: uma nova técnica de consenso. Estud. e Pesqui. em Psicol. 10, 221-241. https://doi.org/10.12957/epp.2010.9029

Chekima, B., Oswald, A.I.@, Wafa, S.A.W.S.K., Chekima, K., 2017. Narrowing the gap: Factors driving organic food consumption. J. Clean. Prod. 166, 1438-1447. https://doi.org/10.1016/j.jclepro.2017.08.086

Cohen, J., 1988. Statistical Power Analysis for the Behavioral Sciences, 2nd ed. Psychology Press, New York.

Dagiliūtè, R., Liobikienè, G., Minelgaite, A., 2018. Sustainability at universities: Students' perceptions from Green and Non-Green universities. J. Clean. Prod. 181, 473-482. https://doi.org/10.1016/j.jclepro.2018.01.213

Diaz-Ruiz, R., Costa-Font, M., Gil, J.M., 2018. Moving ahead from food-related behaviours: an alternative approach to understand household food waste generation. J. Clean. Prod. 172, 1140-1151. https://doi.org/10.1016/j.jclepro.2017.10.148

Edvardsson Björnberg, K., Skogh, I.-B., Strömberg, E., 2015. Integrating social sustainability in engineering education at the KTH Royal Institute of Technology. Int. J. Sustain. High. Educ. 16, 639-649. https://doi.org/10.1108/IJSHE-01-20140010

Fiorini, M., Hoekman, B., 2018. Services trade policy and sustainable development. World Dev. 112, 1-12. https://doi.org/10.1016/j.worlddev.2018.07.015

Gallardo-Vázquez, D., Sanchez-Hernandez, M.I., 2014. Measuring Corporate Social Responsibility for competitive success at a regional level. J. Clean. Prod. 72, 14-22. https://doi.org/10.1016/j.jclepro.2014.02.051 
Gray, D.E., 2017. Doing Research in the Business World. SAGE Publications, London.

GRI, 2018. Consolidated Set of GRI Sustainability Reporting Standards. Netherlands.

Guerra, A., 2017. Integration of sustainability in engineering education. Int. J. Sustain. High. Educ. 18, 436-454. https://doi.org/10.1108/IJSHE-02-2016-0022

Hair, J.F., Hult, G.T.M., Ringle, C., Sarstedt, M., 2014. A primer on partial least squares structural equation modeling (PLS-SEM). Sage Publications, Thousand Oaks.

Hanning, A., Priem Abelsson, A., Lundqvist, U., Svanström, M., 2012. Are we educating engineers for sustainability? Int. J. Sustain. High. Educ. 13, 305-320. https://doi.org/10.1108/14676371211242607

Harring, J.R., Weiss, B. a., Li, M., 2015. Assessing Spurious Interaction Effects in Structural Equation Modeling: A Cautionary Note. Educ. Psychol. Meas. 75, 721738. https://doi.org/10.1177/0013164414565007

Holgaard, J.E., Hadgraft, R., Kolmos, A., Guerra, A., 2016. Strategies for education for sustainable development - Danish and Australian perspectives. J. Clean. Prod. 112, 3479-3491. https://doi.org/10.1016/j.jclepro.2015.09.063

Hollos, D., Blome, C., Foerstl, K., 2012. Does sustainable supplier co-operation affect performance? Examining implications for the triple bottom line. Int. J. Prod. Res. 50, 2968-2986. https://doi.org/10.1080/00207543.2011.582184

Hwang, G.H., Jeong, S.K., Ban, Y.U., 2016. Causal relationship of eco-industrial park development factors: a structural equation analysis. J. Clean. Prod. 114, 180-188. https://doi.org/10.1016/j.jclepro.2015.12.023

IBGC, 2007. Guia de Sustentabilidade para as Empresas.

Iyer-Raniga, U., Andamon, M.M., 2016. Transformative learning: innovating sustainability education in built environment. Int. J. Sustain. High. Educ. 17, 105122. https://doi.org/10.1108/IJSHE-09-2014-0121

Kuei, C., Madu, C.N., Chow, W.S., Chen, Y., 2015. Determinants and associated performance improvement of green supply chain management in China. J. Clean. Prod. 95, 163-173. https://doi.org/10.1016/j.jclepro.2015.02.030

Kumar, V., Haapala, K., Rivera, J., Hutchins, M., Endres, W., Gershenson, J., Michalek, D., Sutherland, J., 2005. Infusing Sustainability Principles into 
Manufacturing/Mechanical Engineering Curricula. J. Manuf. Syst. 24, 215-225.

Laguir, I., Staglianò, R., Elbaz, J., 2015. Does corporate social responsibility affect corporate tax aggressiveness? J. Clean. Prod. 107, 662-675. https://doi.org/10.1016/j.jclepro.2015.05.059

Lamb, E., Mengersen, K., Stewart, K., Attanayake, U., Siciliano, S., 2014. Spatially explicit structural equation modeling. Ecology 95, 2434-2442. https://doi.org/10.1890/13-1997.1

Leal Filho, W., Raath, S., Lazzarini, B., Vargas, V.R., de Souza, L., Anholon, R., Quelhas, O.L.G., Haddad, R., Klavins, M., Orlovic, V.L., 2018. The role of transformation in learning and education for sustainability. J. Clean. Prod. 199, 286295. https://doi.org/10.1016/j.jclepro.2018.07.017

Marques, V.D.L., Filho, C.A., Pereira, F.N., 2018. Tools for the strategic management of stakeholders in civil construction. Brazilian J. Oper. Prod. Manag. 15, 595-609. https://doi.org/10.14488/BJOPM.2018.v15.n4.a13

McCormick, M., Bielefeldt, A.R., Swan, C.W., Paterson, K.G., 2015. Assessing students' motivation to engage in sustainable engineering. Int. J. Sustain. High. Educ. 16, 136154. https://doi.org/10.1108/IJSHE-06-2013-0054

Nejati, M., Rabiei, S., Chiappetta Jabbour, C.J., 2017. Envisioning the invisible: Understanding the synergy between green human resource management and green supply chain management in manufacturing firms in Iran in light of the moderating effect of employees' resistance to change. J. Clean. Prod. 168, 163-172. https://doi.org/10.1016/j.jclepro.2017.08.213

Opoku, A., 2019. Biodiversity and the built environment: Implications for the Sustainable Development Goals (SDGs). Resour. Conserv. Recycl. 141, 1-7. https://doi.org/10.1016/j.resconrec.2018.10.011

Pinheiro, J. de Q., Farias, T.M., Abe-lima, J.Y., 2013. Painel de Especialistas e Estratégia Multimétodos: Reflexoes, Exemplos, Perspectivas. Psico - Rev. Eletrônica PUC RS 44, 184-192.

Ramanujan, D., Zhou, N., Ramani, K., 2019. Integrating environmental sustainability in undergraduate mechanical engineering courses using guided discovery instruction. J. Clean. Prod. 207, 190-203. https://doi.org/10.1016/j.jclepro.2018.09.191 
Rampasso, I.S., Anholon, R., Silva, D., Cooper Ordoñez, R.E., Quelhas, O.L.G., Leal Filho, W., Santa-Eulália, L.A., 2018a. An analysis of the difficulties associated to sustainability insertion in engineering education: Examples from HEIs in Brazil. J. Clean. Prod. 193, 363-371. https://doi.org/10.1016/j.jclepro.2018.05.079

Rampasso, I.S., Anholon, R., Silva, D., Cooper Ordóñez, R.E., Quelhas, O.L.G., SantaEulalia, L.A. De, 2018b. Developing in engineering students a critical analysis about sustainability in productive systems. Int. J. Sustain. High. Educ. IJSHE-03-20180048. https://doi.org/10.1108/IJSHE-03-2018-0048

Rehman, M.A., Seth, D., Shrivastava, R.L., 2016. Impact of green manufacturing practices on organisational performance in Indian context: An empirical study. J. Clean. Prod. 137, 427-448. https://doi.org/10.1016/j.jclepro.2016.07.106

Ringle, C.M., Da Silva, D., Bido, D.D.S., 2014. Structural Equation Modeling with the Smartpls. Rev. Bras. Mark. 13, 56-73. https://doi.org/10.5585/remark.v13i2.2717

Rosati, F., Diniz Faria, L.G., 2018. Addressing the Sustainable Development Goals in sustainability reports: the relationship with institutional factors. J. Clean. Prod. https://doi.org/10.1016/j.jclepro.2018.12.107

Sales Moreira, A.C., 2018. Application of the sustainable logistics plan in the public administration. Brazilian J. Oper. Prod. Manag. 15, 137-142. https://doi.org/10.14488/BJOPM.2018.v15.n1.a12

Saunila, M., Ukko, J., Rantala, T., 2018. Sustainability as a driver of green innovation investment and exploitation. J. Clean. Prod. 179, 631-641. https://doi.org/10.1016/j.jclepro.2017.11.211

Segalàs, J., Mulder, K.F., Ferrer-Balas, D., 2012. What do EESD "experts" think sustainability is? Which pedagogy is suitable to learn it? Int. J. Sustain. High. Educ. 13, 293-304. https://doi.org/10.1108/14676371211242599

Sharma, B., Steward, B., Ong, S.K., Miguez, F.E., 2017. Evaluation of teaching approach and student learning in a multidisciplinary sustainable engineering course. J. Clean. Prod. 142, 4032-4040. https://doi.org/10.1016/j.jclepro.2016.10.046

Srivastava, A., 2018. Standardizing evaluation process: Necessary for achieving SDGs A case study of India. Eval. Program Plann. 69, 118-124. https://doi.org/10.1016/j.evalprogplan.2018.05.001 
Tejedor, G., Segalàs, J., Rosas-Casals, M., 2018. Transdisciplinarity in higher education for sustainability: How discourses are approached in engineering education. J. Clean. Prod. 175, 29-37. https://doi.org/10.1016/j.jclepro.2017.11.085

Thürer, M., Tomašević, I., Stevenson, M., Qu, T., Huisingh, D., 2018. A systematic review of the literature on integrating sustainability into engineering curricula. J. Clean. Prod. 181, 608-617. https://doi.org/10.1016/j.jclepro.2017.12.130

UN, 2017. Global indicator framework for the Sustainable Development Goals and targets of the 2030 Agenda for Sustainable Development.

von Blottnitz, H., Case, J.M., Fraser, D.M., 2015. Sustainable development at the core of undergraduate engineering curriculum reform: a new introductory course in chemical engineering. J. Clean. Prod. 106, 300-307. https://doi.org/10.1016/j.jclepro.2015.01.063

Yuan, X., Zuo, J., 2013. A critical assessment of the Higher Education for Sustainable Development from students' perspectives - A Chinese study. J. Clean. Prod. 48, 108-115. https://doi.org/10.1016/j.jclepro.2012.10.041 